\title{
Knowledge and practice of condom use among first year students at University of the North, South Africa
}

\author{
K Peltzer. Ph.D., Department of Psychology, University of the North
}

\begin{abstract}
The aim of the study is to investigate knowledge and sexual practices with reference to correct use of condoms among first year South African University students. The sample consisted of 206 participants, 146 female and 60 male, the mean age was 20.9 years $(S D=3.4)$, with a range from 17 to 34 years. Results indicated that one third $(29.2 \%)$ of the sample reported never using condoms, $35.4 \%$ always, $19.8 \%$ regularly and $8.5 \%$ irregularly in the past three months. About $90 \%$ levels of correct answers for condom use were found for the items of 'condoms as protection against STD and AIDS', 'expiry date of condoms', and
\end{abstract}

're-using condoms'. More than $15 \%$ were not aware that a condom should be put on before any contact with the vagina. The most common mistakes with respect to condom use were ignorance about the correct moment to put on a condom (56\%), and when to take off a condom (55\%). Male sex and especially increasing recent sexual encounters was associated with correct condom knowledge. The most common reasons for not using a condom were 'I do not have the AIDS virus' and 'I thought I was safe' seems to indicate a low perceived susceptibility. Findings are discussed in view of condom promotion programmes.

\section{Introduction}

Condoms are an integral part of Sexually Transmitted Diseases (STD) and Human Immunodeficiency Virus (HIV)/Acquired Immunodeficiency Syndrome (AIDS) prevention, and their use has increased significantly over the past decade. Correct use of them reduces the risk of HIV transmission by almost 100 percent. Therefore, condom promotion has received considerable attention in the fight against the AIDS pandemic (WHO 1995). This is particularly important in sub-Saharan Africa where HIV transmission is mainly through sexual contact. Yet condom use is among the most difficult issues to address in designing programmes to reduce the sexual transmission of HIV in Africa.

Campbell (1997: 186) summarises for sub-Saharan Africa that negative attitudes toward condom use are often based on cultural factors, e.g. the desire for children and female sexual compliance as ways to achieve economic status. Lule and Gruer (1991: 15-17) found among Ugandan students that only a minority saw the condom as an effective preventive method against HIV/AIDS: most saw it as unsafe or an encouragement to promiscuity. Condoms had been used by $35 \%$ of men and $24 \%$ of women but were currently always used by only $9 \%$ of men and $11 \%$ of women. The condom was approved of by only one quarter of respondents. Kaya and Kau (1994: 12) found among social science students at the University of North West, South Africa, that $84 \%$ felt that the best way of preventing HIV infection was 'using condoms during sexual intercourse'. Kidan and Azeze (1995: 9) surveyed condom use among Ethiopian college students and reasons given for not using condoms included: unavailability (44.3\%), partner trust (43\%), shortage of condoms ( $8 \%$ ), and partner's disagreement $(5.1 \%)$. Zambian
University students felt at greater sexual risk for HIV/AIDS but were less rigorous in condom use than British students (Baggaley et al. 1997: 88). Abdool-Karim et al. (1992: 109) did an explorative qualitative study to find out reasons for lack of condom use among high school students in Natal (South Africa). They complained among others that condom use was not sufficiently well understood and that condoms were not accessible or available when required.

Research also shows that the spread of HIV/AIDS is on the increase. It is expected that the prevalence of AIDS will reach about $27 \%$ of the sexually active population in South Africa by the year 2010 (Webb 1997: 214).

There is a paucity of data concerning male condom use, especially regarding knowledge about the correct use of male condoms by the target group of the youth in South Africa. However, such data are crucial for prevention programmes. Since heterosexual contact and the use of male condoms are the predominant forms of sexual contact and condom use respectively in South Africa, the study was restricted to heterosexual contact and male condoms. Therefore the present study investigates knowledge and sexual practices with reference to correct use of male condoms (prevalence of condom use and factors associated with the use/non-use of condoms) among university students in the Northern Province of South Africa.

The objectives of the study are:

(1) To assess the knowledge about the correct use of condoms;

(2) To determine the frequency of condom use;

(3) To assess the reasons for not using a condom; and

(4) To identify the relationship between independent variables (biographic data, sexual behaviour, condom use) and dependent variables (condom knowledge). 


\section{Methods}

Sample and procedure

The sample consisted of a convenient sample of 206 first year psychology students at the University of the North, $146 \mathrm{fe}-$ male and 60 male, the mean age was 20.9 years $(S D=3.4)$, with a range from 17 to 34 years. Most were Northern Sotho (73.6\%), Tsonga (13.2\%), Venda (4.4\%), Zulu (3.3\%), and others (5.5\%). The students were clearly informed that the purpose of the survey was to find out about the use and knowledge of the condom and that their responses would be totally anonymous. Each student was requested to complete the questionnaire or indicate that he or she did not wish to do so. In either cases, they were asked to put it in the envelope provided and hand it back to the researcher within approximately half an hour.

\section{Measure}

The instrument, which was essentially a questionnaire, was pre-tested on 15 male and 15 female students, who did not form of the final sample. The final questionnaire consisted of questions about: (a) biographic data ( 8 items), (b) sexual activity and male condom use (5 items) (cf. Eshetu et al. 1997: 11), (c) knowledge about correct use of male condoms ( 10 items) and (d) reasons for not using a male condom ( 18 items) (cf. Calzavara 1998: 277). Knowledge about correct use of condoms was evaluated as per standard guidelines for use of condoms (Sharma et al. 1997: 711, WHO 1990). There were ten closed-ended questions, each with one possible correct answer (e.g. when to put on a condom, how to use it correctly, how and when to take it off, the use of lubricants, etc.) and for each correct answer one point was awarded; the total points comprised the knowledge score range from 0 to 10 . Regarding reasons for not using condoms, respondents were given a list of 18 reasons and asked to indicate which applied to them.

For the 10-item scale on knowledge about correct use of condoms the Cronbach alpha as well as split-half reliability coefficient were .78 for this sample, for the 18 -item scale on reasons for not using a condom the Cronbach alpha as well as split-half reliability coefficients were .72 and .68 for this sample, and for the 5 -items on sexual activity and condom use the Cronbach alpha as well as split-half reliability coefficients were .67 and .65 respectively for this sample.

\section{Results}

Table 1 indicates the knowledge about correct condom use among the participants.

About $90 \%$ levels of correct answers were found for the items of "condoms as protection against STD and AIDS', 'expiry date of condoms', and 're-using condoms'. More than $15 \%$ were not aware that a condom should be put on before any contact with the vagina.

The most common mistakes with respect to condom use were ignorance about the correct moment to put on a condom (56\%), when to take off a condom (55\%), and whether a condom should be unrolled before being put on the penis (28\%), in this order. Male students (7.31 mean correct answers) had a higher correct knowledge on condom use than female students $(6.76$ mean correct answers) did. In particular, there was a significant gender difference on items 8 'Is it essential for a person using a condom to withdraw his penis immediately after ejaculation?' and 9 'Is it alright to put on a condom just before ejaculation' (both: $\mathrm{p}<.01$ ).

Table 2 indicates sexual activity and condoms use by the participants.

More than half of the respondents (57\%) was aware of condom use prior to their first sexual encounter while less than $20 \%$ used a condom on first sex. About $40 \%$ of male students (46.5\%) and female students $(38.6 \%)$ had a sexual encounter within the last month and about $60 \%$ within the last three months. Regarding the frequency of sexual encounter during the last three months $39.6 \%$ of men and $21.1 \%$ of women said three times or more, and $20.7 \%$ of the men and $28.7 \%$ of the women reported none. Almost one third (29.2\%) of the sample reported never using condoms, $35.4 \%$ always, $19.8 \%$ regularly and $8.5 \%$ irregularly in the past three months.

Table 3 indicates factors associated with knowledge about condom use by the participants.

There is a significant relationship between sex, frequency of sexual encounters in the last three months and condom knowledge. Men had more correct condom knowledge than women, and increasing recent sexual encounters seem to be associated with correct condom knowledge. Current condom use and condoms use intentions seem not to be related to correct knowl-

\section{Table 1: Knowledge about correct male condom use by gender and rank in percent of "yes" answers (as against "no" answers)}

\begin{tabular}{|l|l|l|l|}
\hline Items & Male & Female & Tota\# \\
\hline 1. Do condoms offer protection against STDs? & 93 & 90 & 91 \\
\hline 2. Do condoms offer protection against AIDS? & 86 & 91 & 89 \\
\hline 3. Do condoms have an expiry date? & 95 & 86 & 90 \\
\hline 4. Can a condom be re-used? ® & 88 & 88 & 88 \\
\hline $\begin{array}{l}\text { 5. Should a condom be checked for leaks } \\
\text { and holes? }\end{array}$ & 88 & 86 & 87 \\
\hline $\begin{array}{l}\text { 6. Can an oil-based lubricant (e.g. oil, Vaseline, } \\
\text { cold cream) be used with a condom? } \circledR\end{array}$ & 84 & 88 & 86 \\
\hline $\begin{array}{l}\text { 7. Should a condom be put on before any } \\
\text { contact with the vagina? }\end{array}$ & 81 & 85 & 83 \\
\hline $\begin{array}{l}\text { 8. Should a condom be unrolled before being } \\
\text { put on the penis? ® }\end{array}$ & 75 & 69 & 72 \\
\hline $\begin{array}{l}\text { 9. Is it essential for a person using a condom } \\
\text { to withdraw his penis immediately after ejaculation? }\end{array}$ & 56 & 34 & 45 \\
\hline $\begin{array}{l}\text { 10. Is it all right to put on a condom just before } \\
\text { ejaculation? } \circledast\end{array}$ & 53 & 35 & 44 \\
\hline
\end{tabular}

(B) Reverse scored, \#Total=Percent of total sample 
dom use was high in this sample. In a study among sexu-

\begin{tabular}{|c|c|c|c|c|}
\hline \multicolumn{2}{|l|}{ Item } & Male & Female & Total\# \\
\hline \multicolumn{2}{|c|}{ Knowledge of condom prior to the first sexual encounter } & 54 & 58 & 57 \\
\hline \multicolumn{2}{|c|}{ Use of condom on the first sexual encounter } & 17 & 19 & 18 \\
\hline Last sexual encounter & $\begin{array}{l}\text {-none } \\
-1-2 \text { weeks } \\
-3-4 \text { weeks } \\
-1-3 \text { months } \\
\text {-more than } 3 \text { months }\end{array}$ & $\begin{array}{l}05.2 \\
24.1 \\
22.4 \\
19.0 \\
29.3\end{array}$ & $\begin{array}{l}07.9 \\
30.7 \\
07.9 \\
20.7 \\
32.9\end{array}$ & $\begin{array}{l}6.6 \\
27.4 \\
15.2 \\
19.9 \\
31.1 \\
\end{array}$ \\
\hline Frequency of sexual en & $\begin{array}{l}\text { ring the last } 3 \text { months } \\
\text {-None } \\
\text {-Once } \\
\text {-Twice } \\
\text {-Three times } \\
\text {-Four or more }\end{array}$ & $\begin{array}{l}20.7 \\
19.0 \\
20.7 \\
15.5 \\
24.1\end{array}$ & $\begin{array}{l}28.7 \\
30.8 \\
17.5 \\
09.8 \\
13.3\end{array}$ & $\begin{array}{l}24.7 \\
24.9 \\
19.1 \\
12.7 \\
18.7\end{array}$ \\
\hline \multicolumn{2}{|c|}{$\begin{array}{ll}\text { Condom use when having sexual intercourse in the } \\
\text { past } 3 \text { months } & \text {-every time } \\
& \text {-regular }{ }^{1} \\
& \text {-irregular }{ }^{2} \\
& \text {-never }\end{array}$} & $\begin{array}{l}37.5 \\
17.9 \\
10.7 \\
25.0\end{array}$ & $\begin{array}{l}33.3 \\
21.6 \\
06.3 \\
33.3\end{array}$ & $\begin{array}{l}35.4 \\
19.8 \\
08.5 \\
29.2\end{array}$ \\
\hline
\end{tabular}

${ }^{1}$ Regular: almost always, more often than not

${ }^{2}$ Irregular: about half the time, somewhat less than half the time, rarely

\#Total=Percent of total sample edge about condoms.

Table 4 indicates reasons for not using condoms in the past.

The most common reasons for not using a condom were ' $I$ do not have the AIDS virus' (65\%), 'I thought I was safe' (61\%)', and 'I was with my steady sex partner' (59\%). On most items men scored higher than women on reasons for not using condoms. Striking is that $26 \%$ of the women and $14 \%$ of the men said that they did not use a condom because they were forced to have sex against their will.

There was a significant relationship between reasons for not using a condom (in particular 'I didn't think of using a condom', 'I find condoms painful', and 'I was using alcohol or drugs') and condom use intentions ( $\mathrm{p}<05)$. Younger age was associated with 'I can't obtain condoms here', 'I find condoms painful', 'I thought I was safe', 'Wanted pregnancy', and 'My partner said he or she did not have the AIDS virus'. ally active men in India a much higher level of ignorance about condom use was found. However, the type of the most common mistakes were similar as in this sample, e.g. the correct moment to put on a condom ( $10.1 \%$ correct answers), when to take off a condom (13.7\% correct answers), and whether a condom should be unrolled before being put on the penis (12.9\% correct answers).

In the following, factors identified in this study are highlighted, which should be incorporated into HIV/AIDS prevention programmes: (1) Men had more knowledge than women about correct male condom use, and increasing recent sexual encounters seem to be associated with correct condom knowledge. (2) The most common reasons for not using a condom were 'I do not have the AIDS virus' and 'I thought I was safe' seems to indicate a low perceived susceptibility. (3) One of the significant factors associated with condom use intentions was 'I find condoms painful'. (4) Younger age was associated with unavailability of condoms, low perceived susceptibility and the wish for pregnancy. (5) Barriers between (steady) partners to use condoms such as 'my partner did not want to use one' (34\%), 'could not talk about it' (27\%), and 'forced to have sex against my will (17\%). (6) The reported barriers and unavailability of condoms such as 'too embarrassed to get condoms' (23\%), 'I can't obtained condoms here' (18\%) or 'I could not

\section{Discussion}

Table 3: Factors associated with knowledge about condom use

In this study almost one-third (29.2\%) of the sample reported never using male condoms, $35.4 \%$ always, $19.8 \%$ regularly and $8.5 \%$ irregularly in the past three months. This finding is similar to that found in other studies, e.g. among Ugandan students the frequency of condom use was reported as: always, $29 \%$ male users, $49 \%$ female users; mostly, $24 \%$ males, $20 \%$ females; and sometimes, $47 \%$ male and $31 \%$ female (Lule \& Gruer 1991: 17). The use female condoms should also be studied.

The overall knowledge about correct con-

\begin{tabular}{|l|l|}
\hline Independent variables & Total condom knowledge score \\
\hline & $p$ \\
\hline Age & -.054 \\
\hline Sex & $.138^{*}$ \\
\hline $\begin{array}{l}\text { Number of sexual encounters in last } \\
3 \text { months }\end{array}$ & $.254^{* *}$ \\
\hline Use of condom in last 3 months & .021 \\
\hline Condom use intention & .100 \\
\hline
\end{tabular}


Table 4: Ranked responses of reasons for not using a male condom in the past by gender, current male condom use, and male condom use intentions and in percent of "yes" answers (as against "no" answers)

\begin{tabular}{|c|c|c|c|c|c|c|c|}
\hline \multirow[t]{2}{*}{ Item } & \multirow{2}{*}{$\sum_{\Sigma}^{\bar{\Xi}}$} & \multirow{2}{*}{ 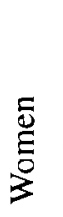 } & \multirow{2}{*}{ 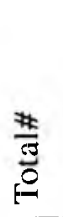 } & $\begin{array}{l}\bar{\Xi} \\
\bar{\Xi} \\
0\end{array}$ & $\underset{8}{8}$ & 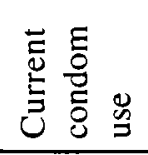 & 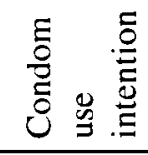 \\
\hline & & & & $p$ & $p$ & $p$ & $p$ \\
\hline 1. I do not have the AIDS virus & 74 & 58 & 65 & -122 & -.049 & .014 & .153 \\
\hline 2. I thought I was safe. & 67 & 55 & 61 & -114 & $-.166^{*}$ & $-.143^{*}$ & $.167 *$ \\
\hline 3. I was with a steadv sex partner & 60 & 57 & 59 & -.029 & -.101 & -.006 & .076 \\
\hline 4. The sex was so exciting & 48 & 37 & 48 & -101 & -.008 & -.008 & .071 \\
\hline $\begin{array}{l}\text { 5. My partner said he or she did not have the } \\
\text { AIDS virus }\end{array}$ & 61 & 35 & 48 & $.152 *$ & $-.142^{*}$ & -.096 & .102 \\
\hline 6. My partner did not want to use one & 44 & 30 & 37 & -.130 & -.037 & .037 & $.174 *$ \\
\hline 7. I did not have a condom at that time & 30 & 34 & 32 & .038 & -.009 & -.065 & 0.57 \\
\hline 8. I didn't think of using a condom & 36 & 26 & 31 & -101 & -.055 & .003 & $.229 * *$ \\
\hline 9. Could not talk about it & 30 & 26 & 28 & -.037 & .079 & -.035 & .001 \\
\hline 10. I did not want to use one & 32 & 20 & 26 & -.123 & -.037 & -.071 & $.179 *$ \\
\hline 11. I was too embarrassed to get condoms & 23 & 23 & 23 & .003 & .014 & -.086 & $.146^{*}$ \\
\hline $\begin{array}{l}\text { 12. My partner got angry for suggesting us. } \\
\text { ing one }\end{array}$ & 29 & 17 & 23 & -.125 & -.070 & -.050 & .080 \\
\hline 13. I was forced to have sex against my will & 14 & 26 & 20 & $-.148^{*}$ & -.021 & -.035 & .130 \\
\hline 14. I can't obtain condoms here & 16 & 19 & 18 & .033 & $-.240^{* *}$ & -.083 & .067 \\
\hline 15. I could not afford to buy any condoms & 25 & 10 & 18 & $-.182 *$ & -.064 & -.024 & .102 \\
\hline 16. I find condoms painful & 14 & 19 & 17 & .059 & $-.182 * *$ & .100 & $.219 *$ \\
\hline 17. Wanted pregnancy & 14 & 13 & 14 & -.021 & $-.144 *$ & .044 & $171^{*}$ \\
\hline 18. I was using alcohol or drugs & 18 & 10 & 14 & -.109 & -.093 & -.035 & $.192 * *$ \\
\hline
\end{tabular}


afford to buy any condoms' (15\%). Nicholas (1999: 893) suggests from a survey of South African university students that condom-vending machines and a wider range of distribution points for free condoms could ease the unpleasentness.

Education programmes should foster positive attitudes toward condom use and teach mechanics for effective use.

The study has the limitation that only a convenient sample of psychology students at the University of the North was chosen. This would limit the extent of the generalisations of the results of this research to other students in South Africa.

\section{Acknowledgements}

I thank the University of the North for the financial support and Rita Olwagen for statistical assistance.

\section{References}

ABDOOL-KARIM SS, ABDOOL-KARIM Q, PRESTONWHYTE E \& SANKAR N 1992: Reasons for lack of condom use among high school students. South African Medical Journal 82(2): 107-110.

\section{BAGGALEY R. DROBNIEWSKI F, POZNIAK A, CHIPANTA} D, TEMBO M \& GODFREY-FAUSSETT P 1997: Knowledge and attitudes to HIV and AIDS and sexual practices among University students in Lusaka, Zambia and London, England. Journal of the Royal Society of Health 117: 88-94.

CALZAVARA LM, BURCHELLAN, MEYERST, BULLOCK SL, ESCOBAR M \& COCKERILL R 1998: Condom use among aboriginal people in Ontario, Canada. International Journal of STD \& AIDS 9: 272-279.

CAMPBELL T 1997: How can psychological theory help to promote condom use in sub-Saharan African developing countries. Journal of the Royal Society of Health 117: 186-191.

ESHETU F, ZAKUS D \& KEBEDE D 1997: The attitudes of students, parents and teachers towards the promotion and provision of condoms for adolescents in Addis Ababa. Ethiopian Journal of Health Development 1 1:7-16.

KAYA HO \& KAU M 1994: Knowledge, attitudes and practice in regard to AIDS: the case of social science students at the University of Bophuthatswana. Curationis 17: 10-14.

KIDAN KG \& AZEZE B 1995: Survey of condom use among college students. Ethiopian Journal of Health Development 9: $7-11$.

LULE GS \& GRUER LD 1991: Sexual behaviour and use of the condom among Ugandan students. AIDS CARE 3: 11-19.

NICHOLAS LJ 1999: Black South African students' beliefs and sttitudes about condoms. Psvchological Reports 83: 891894.

SHARMA V; DAVE S; SHARMA A \& CHAUHAN P 1997: Condoms: mis-use=non-use. The condom equation in Gujarat, India. AIDS CARE 9: 707-713.

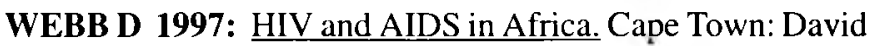
Philip.

WORLD HEALTH ORGANIZATION. 1990. Global programme on AIDS: orientation manual: condom and virucide services. Geneva: author.

WORLD HEALTH ORGANISATION. 1995. Condom promotion for AIDS prevention. Geneva: author. 